DOI: $10.14451 / 1.193 .472$

\title{
УСПЕХИ КУРСКОЙ ОБЛАСТИ В РОСТЕ ЭКОНОМИКИ РАСТЕНИЕВОДСТВА
}

\author{
(C) 2020 Штоколова Карина Владимировна \\ Курская Государственная сельскохозяйственная академия имени И.И.Иванова, Россия, Курск \\ E-mail: karina.shtokolova@mail.ru
}

(c) 2020 Федулов Михаил Александрович

Курская Государственная сельскохозяйственная академия имени И. И. Иванова, Россия, Курск

E-mail: 46fedulov@gmail.com

В статье рассматриваются успехи Курской области в росте экономики растениеводства в условиях реализации стратегии импортозамещения начиная с 2015 г., проанализировано изменение размера и структуры посевных площадей области, а также валовых сборов основных видов возделываемых культур. Установлено, что отрасли растениеводства региона имеют активное динамичное развитие по традиционным видам культур, что во многом определяет его аграрную специализацию. Вместе с тем, в последние годы стали набирать обороты относительно новые для области направления - подсолнечник и соя.

Ключевые слова: Курская область, растениеводство, посевные площади, урожайность, валовой сбор, импортозамещение.

Развитие агропромышленного комплекса страны сегодня входит в число наиболее значимых социально-экономических задач, что обусловлено сложившейся политической напряженностью и введенными двусторонними экономическими санкциями [1]. Как следствие, укрепление национальной безопасности России, в том числе и в части продовольственного обеспечения, стало как никогда актуальным [2]. Это значительно повысило роль отрасли сельского хозяйства и аграрно-ориентированных регионов страны, к которым относится и Курская область [3]. Регион обладает благоприятными почвенно-климатическими условиями, что формирует предпосылки к развитию высокого аграрного потенциала [4].

Несмотря на активное развитие свиноводства, по производству которого Курская область вышла на лидирующие позиции, зернопродуктовый и свеклосахарный подкомплексы сегодня также успешно наращивают темпы производства [5]. Благодаря этому область входит в топ-10 страны по производству зерна и свеклы сахарной фабричной, чем и определяется его отраслевая специализация [6]. Традиционно основу растениеводства области составляет зерновое хозяйство, являющееся системообразующим элементов севооборота и формирующее хорошую кормовую базу для развития отраслей животноводства [7].

Вместе с тем, в последние годы происходит снижение доли зернового клина, что в большинстве своем является положительной тенденцией, свидетельствующей о диверсификации растениеводства в области [8]. Такой подход способствует повышению общей эффективности растениеводства за счет увеличения прибыли и снижения зависимости от урожайности основополагающих культур [9]. В результате, область характеризуется динамичными изменениями в производстве подсолнечника и сои, что способствует росту экономических показателей от растениеводства и делает его центральным звеном курских аграриев [10]. Значимость развития отраслей растениеводства в Курской области обусловлена его возросшей ролью в продовольственном обеспечении регионов страны по ключевым продуктам, таким как зерно и сахар, а также высокой перспективностью и конкурентоспособностью растениеводства как основы регионального агропроизводства в новых экономических условиях [11].

Говоря об общих тенденциях развития аграрного сектора в регионе, можно отметить, что в период 2016-2018 гг. произошел рост доли сельского хозяйства в структуре ВРП до $18,1 \%$, что свидетельствует о повышении эффективности функционирования отрасли. При этом отмечается и положительный рост объема инвестиций, направленных на развитие сельского хозяйства, составивший в 2018 году 22,7 млрд. руб. Это характеризует прирост на уровне $35 \%$, 
что подтверждает повышенный интерес бизнеса к отрасли в текущих экономических условиях (рисунок 1).

Стоимостной объем сельскохозяйственной продукции региона за последние 5 лет вырос вдвое (57,8\%), составив в 2019 году 179,6 млрд. руб. При этом, в разрезе основных отраслей сельского хозяйства, такой прирост обусловлен именно активным развитием растениеводства, объем продукции которого увеличился на 83,9\% за 5 лет. В 2019 году стоимость продукции растениеводства составила 122,1 млрд. руб., а удельный вес в общей производственной структуре достиг $68 \%$ в сравнении с $58,3 \%$ в базисном году, что свидетельствует о главенствующей роли растениеводческой продукции и тенденции к ее усилению в последние годы.

При этом объем производимой животноводческой продукции также растет в исследуемом периоде $-21,3 \%$ за 5 лет, в результате чего его стоимость в 2019 году составила 57,5 млрд. руб. в сравнении с 47,4 млрд. руб. в базисном году. Од- нако удельный вес продукции животноводства снизился с $41,7 \%$ до $32 \%$, что позволяет сделать вывод о динамичном развитии отраслей растениеводства в Курской области и смещении вектора развития агропромышленного комплекса в данную сторону (таблица 1).

Данное обстоятельство также подтверждается и фактом роста объема посевных площадей в регионе: если в 2015 году их площадь составляла 1,59 млн. га, то в 2019 году возросла до 1,65 млн. га. Среди основных видов сельскохозяйственных культур, воспроизводимых в регионе, устойчивая тенденция к росту посевных площадей отмечается для технических культур, объем посевов которых за 5 лет вырос вдвое и составил 570,7 тыс. га, что даже больше, чем посевная площадь озимых зерновых культур. Посевные площади прочих видов сельскохозяйственных культур в последние 5 лет снижаются, в наибольшей степени - кормовых и овощебахчевых, а также картофеля (таблица 2).

В структуре посевных площадей за 5 лет про-

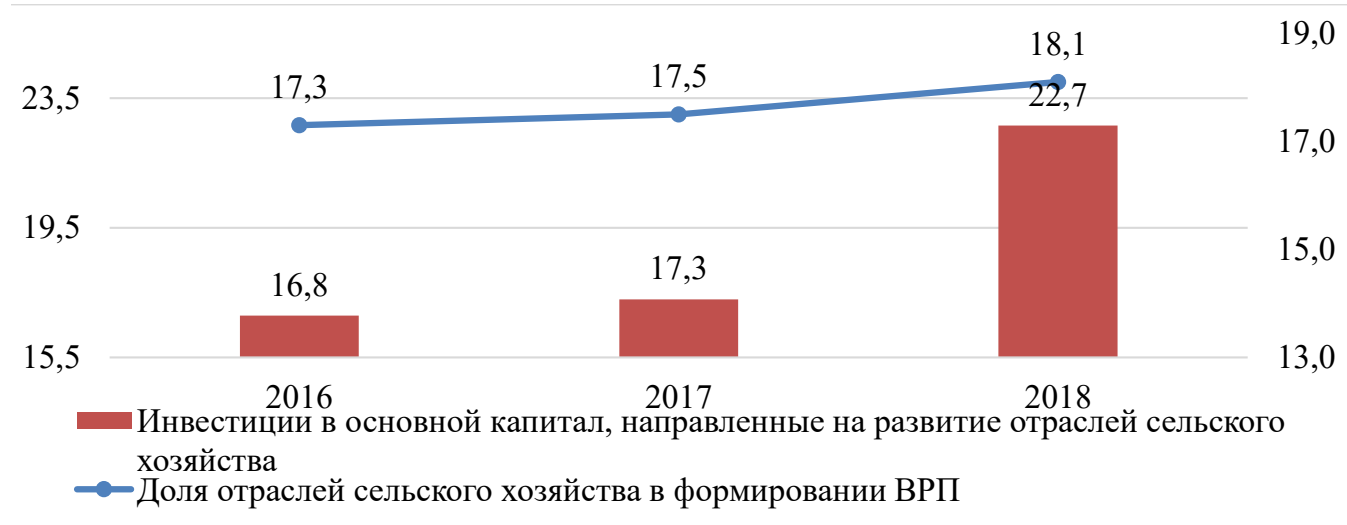

Рисунок 1. Динамика доли отраслей сельского хозяйства в формировании ВРП (\%) и объема инвестиций в основной капитал, направленных на развитие отраслей сельского хозяйства (млрд. руб.), в Курской области в 2016-2018 гг.

Таблица 1. Динамика и структура производства продукции сельского хозяйства в Курской области в 2015-2019 гг.

\begin{tabular}{|l|c|c|c|c|c|c|}
\hline \multirow{2}{*}{\multicolumn{1}{|c|}{ Показатель }} & \multicolumn{5}{c|}{ Значение } & $\begin{array}{c}\text { Изменение } \\
\text { в 2019 г. } \\
\text { к 2015 г., \% }\end{array}$ \\
\cline { 2 - 8 } & 2015 & 2016 & 2017 & 2018 & 2019 & 57,8 \\
\hline $\begin{array}{l}\text { Продукция сельского хозяйства (млрд. руб.), } \\
\text { в т.ч.: }\end{array}$ & 113,8 & 124,4 & 130,9 & 146,7 & 179,6 & 83,9 \\
\hline - продукция растениеводства & 66,4 & 76,1 & 75,7 & 88,7 & 122,1 & 21,3 \\
\hline - продукция животноводства & 47,4 & 48,2 & 55,2 & 58 & 57,5 & \multicolumn{5}{|c|}{} \\
\hline \multicolumn{7}{|c|}{ Структура, \% } \\
\hline - продукция растениеводства & 58,3 & 61,2 & 57,8 & 60,5 & 68,0 & 16,5 \\
\hline - продукция животноводства & 41,7 & 38,7 & 42,2 & 39,5 & 32,0 & $-23,1$ \\
\hline
\end{tabular}


Таблица 2. Динамика посевных площадей в разрезе основных культур в Курской области в 2015-2019 гг.

\begin{tabular}{|c|c|c|c|c|c|c|}
\hline \multirow{2}{*}{ Показатель } & \multicolumn{5}{|c|}{ Значение, тыс. га } & \multirow{2}{*}{$\begin{array}{l}\text { Изменение } \\
\text { в } 2019 \text { г. } \\
\text { к } 2015 \text { г., \% }\end{array}$} \\
\hline & 2015 & 2016 & 2017 & 2018 & 2019 & \\
\hline Посевная площадь всех культур, в т.ч.: & 1586,9 & 1626,3 & 1625,7 & 1617,2 & 1644,7 & 3,6 \\
\hline Зерновых и зернобобовых & 1066 & 1056,9 & 1023,4 & 969,1 & 967,6 & $-9,2$ \\
\hline - озимых & 525,7 & 509,8 & 486,8 & 494 & 458 & $-12,9$ \\
\hline - яровых & 540,3 & 547,1 & 536,6 & 475,1 & 509,6 & $-5,7$ \\
\hline Технических & 378,2 & 438,7 & 480,1 & 538,5 & 570,7 & 50,9 \\
\hline Кормовых & 99,7 & 91,1 & 84,3 & 72,6 & 72,8 & $-27,0$ \\
\hline Картофеля и овощебахчевых & 42,9 & 39,6 & 37,9 & 37 & 33,6 & $-21,7$ \\
\hline
\end{tabular}

изошли следующие изменения: удельный вес технических культур возрос с 23,8\% до 34,7\%, в результате чего данное направление стало подавляющим в растениеводстве региона. Также, несмотря на незначительное снижение, существенная доля приходится на яровые и озимые культуры, которые в совокупности составляют основу посевов в области. При этом наименьшее распространение в регионе получили кормовые и овощебахчевые культуры с картофелем, посевные площади которых являются незначительными и имеют тенденцию к еще большему уменьшению за последние 5 лет (рисунок 2).

Помимо посевных площадей, важное значение имеет объем валового сбора, который зависит от ряда факторов, главенствующим среди которых является урожайность. Сама же урожайность как качественный показатель является многофакторной категорией и находится в прямой зависимости от климатических условий, уровня осадков, объема вносимых удобрений, технологий выращивания и сортов сельскохозяйственных культур [12].

Оценивая урожайность основных видов культур, возделываемых в Курской области, можно отметить устойчивую тенденцию к повышению эффективности выращивания зерна и свеклы сахарной фабричной, которых к 2019 году стали собирать более чем в 2 раза больше относительно 2015 года. Так, в 2019 году урожайность зерна составила 52 ц/га, а сахарной свеклы - 539 ц/га.

Также наблюдается незначительный рост урожайности картофеля, которая в 2019 году достигла 166 ц/га. Эффективность возделывания подсолнечника в регионе хоть и варьирует в исследуемом периоде, но за 5 лет имеет общую тенденцию к увеличению с 21,9 ц/га до 30 ц/га, что характеризует прирост на уровне $37 \%$ и является значительным результатом, свидетельствующим о качественном росте урожайности данной культуры. Урожайность выращиваемых в области овощей в 2019 году составила 160 ц/га, что ниже уровня базисного года, в котором показатель был равен 164 ц/га. Также значительно за 5 лет возросла эффективность выращивания сои - ее урожайность выросла на 47\% и в 2019 году составила 22 ц/га (рисунок 3).

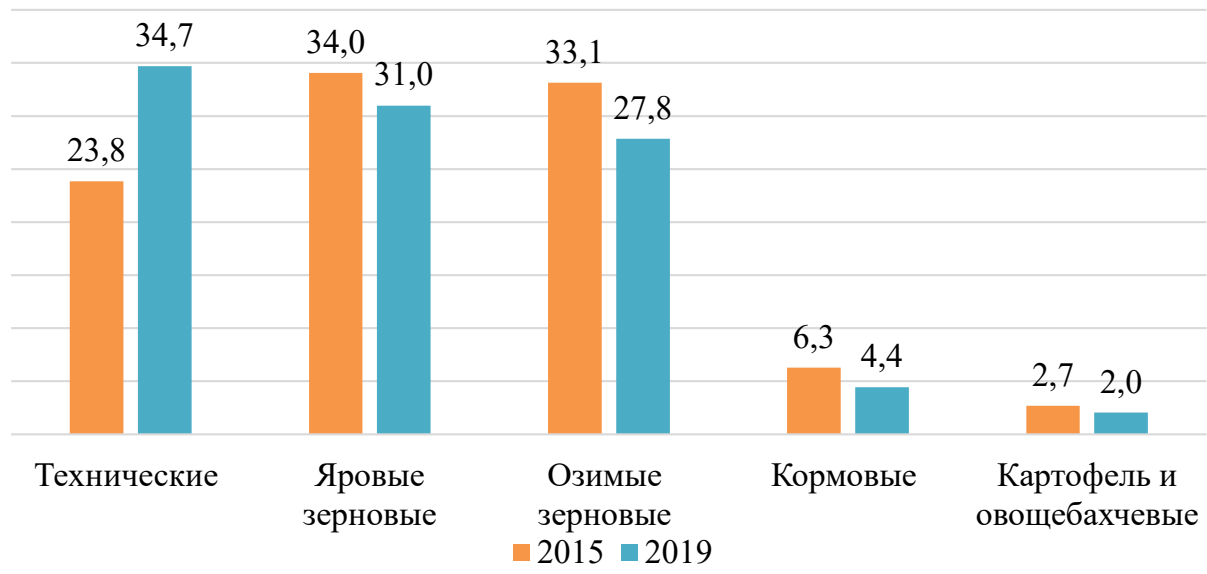

Рисунок 2. Структура посевных площадей Курской области по основным видам сельскохозяйственных культур в 2015 и 2019 гг., \% 


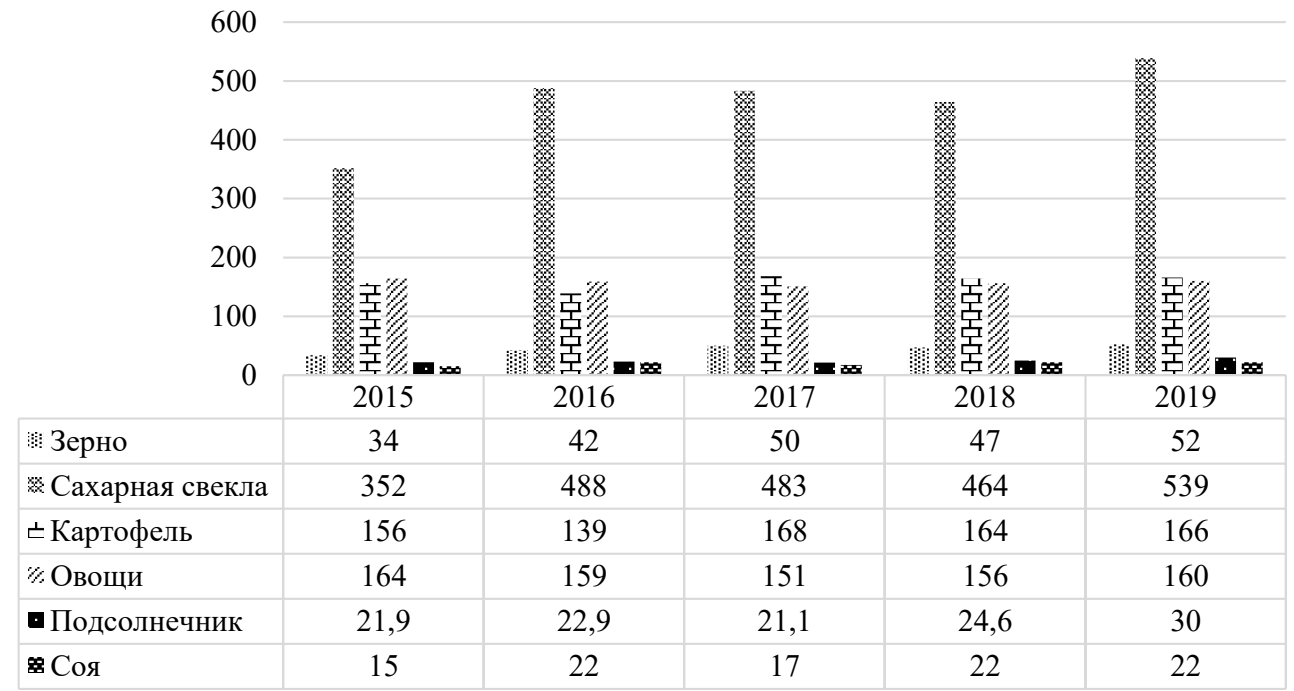

Рисунок 3. Динамика урожайности основных видов сельскохозяйственных культур в Курской области в 2015-2019 гг., ц/га

Валовой сбор основных сельскохозяйственных культур в регионе, как конечный результат функционирования отрасли растениеводства, по большинству позиций также имеет тенденцию к росту. Так, валовой сбор зерна в области к 2019 году вырос до 4,98 млн. т., что на 38,5\% больше уровня базисного года. Рекордно вырос объем валового сбора свеклы сахарной фабричной - с 3,4 млн. т. до 5,4 млн. т., что является наибольшим значением среди всех видов сельскохозяйственных культур и соответствует приросту на уровне $57,4 \%$ (рисунок 4).

Рекордно вырос объем валового сбора свеклы сахарной фабричной - с 3,4 млн. т. до 5,4 млн. т., что является наибольшим значением среди всех видов сельскохозяйственных культур и соответствует приросту на уровне $57,4 \%$. Вме- сте с тем, лидером по приросту валового сбора за 5 лет является соя, которой в 2015 году было собрано 170 тыс. т., а в 2019 году - уже 625 тыс. т., что в 2,7 раза больше базисного периода. Также динамично растет валовой сбор подсолнечника, прирост объем которого за 5 лет равен 60,5\%, а абсолютное значение достигло 427 тыс. т. Объем валового сбора овощей за 5 лет практически не изменился и составляет около 100 тыс. т., что свидетельствует о том, что данное направление не получает активное развитие в регионе. Несмотря на волнообразное изменение объемов валового сбора, общая тенденция является отрицательной: за 5 лет валовой сбор картофеля сократился на $20 \%$, составив на конец периода 466 тыс. т.

Проведенное исследование позволяет сде-

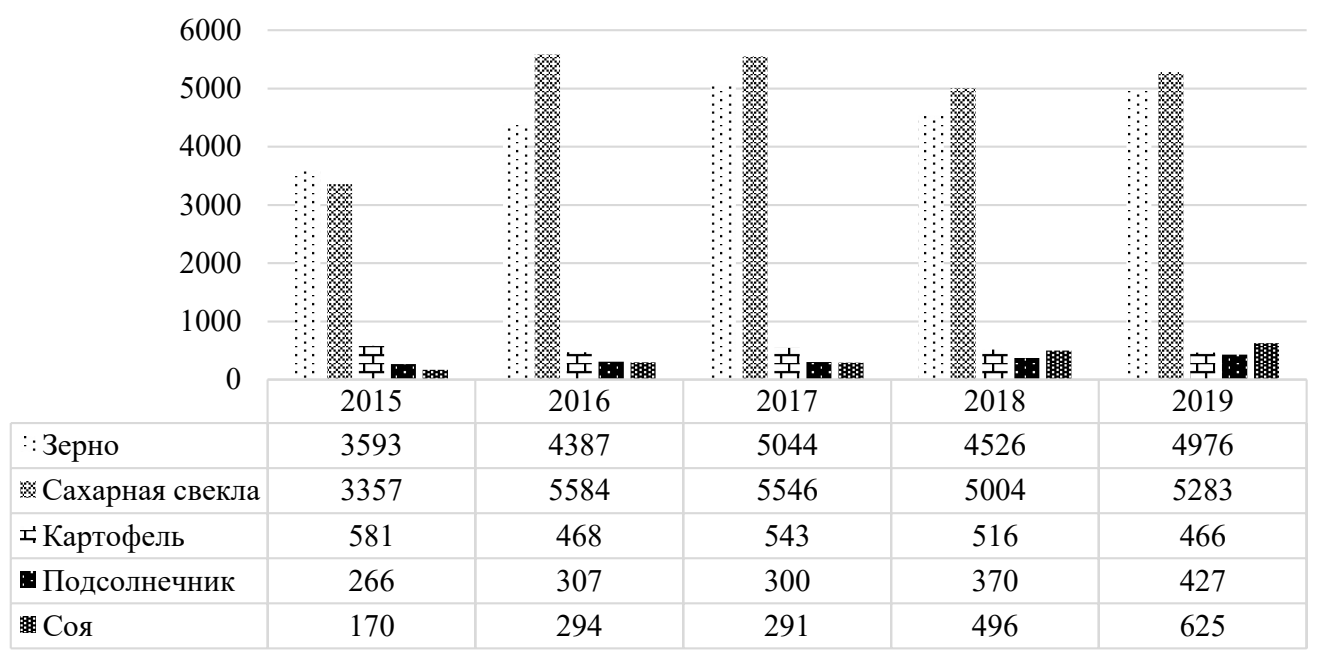

Рисунок 4. Динамика валового сбора основных видов сельскохозяйственных культур в Курской области в 2015-2019 гг., тыс. т. 
лать вывод о том, что сегодня Курская область является своего рода житницей ЦФО, о чем свидетельствует активное динамичное развитие отрасли растениеводства региона по традиционным видам культур, в частности, зерновым и свекле, что во многом и определяет его аграрную специализацию. Вместе с тем, в последние годы стали набирать обороты относительно новые для области направления - масличные культуры подсолнечник и соя, темпы увеличения объемов выращивания которых являются высокими. Данные преобразования, с точки развития агробизнеса в регионе, являются положительными, поскольку способствуют дифференциации имеющегося сельскохозяйственного производства и его расширения за счет новых направлений.

Также стоит отметить положительную тенденцию к росту посевных площадей в Курской области, что свидетельствует об интенсификации использования имеющихся на территории региона земельных ресурсов, а также подчер- кивает рост интереса со стороны инвесторов и аграриев к развитию сельского хозяйства. Структура посевных площадей является сбалансированной, акцент сделан на наиболее значимые и конкурентоспособные виды культур, однако происходит постепенное увеличение доли новых перспективных направлений в общем объеме посевов. Существенное увеличение объемов валовых сборов в регионе произошло в наибольшей степени за счет роста урожайности возделываемых сельскохозяйственных культур, что может быть обусловлено совершенствованием применяемых в агротехнологий. Следовательно, можно говорить о том, что сегодня в Курской области растениеводство активно развивается, что, в том числе, связано и с ростом интереса агроинвесторов к отрасли в условиях импортозамещения и реализации государственной политики по поддержке развития агропромышленного комплекса.

\section{Библиографический список}

1. Соловьева Т.Н., Пожидаева Н. А., Зюкин Д. А. Государственное регулирование и импортозамещение продовольственной продукции: проблемы и решения // Экономика сельскохозяйственных и перерабатывающих предприятий. 2016. № 11. С. 17-20.

2. Силаева Л.П., Кондрашова О. Н. Основные тенденции развития растениеводства в стране // Вестник Курской государственной сельскохозяйственной академии. 2016. № 3. С. 6-10.

3. Зюкин Д.А. Стратегическое управление природно-экономическим потенциалом зернопродуктового подкомплекса: цели и задачи // Региональный вестник. 2017. № 1 (6). С. 43-45.

4. Векленко В.И., НоздрачеваЕ.Н., Степкина И.И. Сложившиеся тенденции в развитии растениеводства Курской области // Вестник Курской государственной сельскохозяйственной академии. 2018. № 1. С. 62-65.

5. Зюкин Д.А., ПожидаеваН.А., Беляев С.А., Горяинова О.Н., Наджафова М.Н. О пути развития сельскохозяйственного производства региона // Экономика и предпринимательство. 2015. № 1 (54). С. $262-266$.

6. Векленко В.И., Ноздрачева Е.Н., Степкина И. И., Золотарев А. А. Современный уровень эффективности растениеводства в курской области //Вестник Курской государственной сельскохозяйственной академии. 2017. № 9. С. 58-62.

7. Михилев А.В., Стариев С.В., Старцева Л. В., Ноздрачева Е.Н. Импортозамещение - проблемы и пути реализации // Вестник Курской государственной сельскохозяйственной академии. 2018. № 5. С. 163-165.

8. Зюкин Д.А., Святова О.В., Пожидаева Н. А., Левченко В.А. О государственной поддержке сельскохозяйственного производства в регионе: состояние, тенденции, перспективы // Вестник Курской государственной сельскохозяйственной академии. 2015. № 2. С. 9-12.

9. Алтухов А.И., Солнцева О.В. К оценке пространственного развития сельскохозяйственного производства // Вестник Курской государственной сельскохозяйственной академии. 2019. № 8. С. 181-191.

10. Головин А.А., Головин А.А., Спицына А. О., Гололобова М.А., Бароян А.А. Оценка эффективности функционирования сельскохозяйственных организаций центрально-чернозёмного экономического района // Вестник евразийской науки. 2019. Т. 11. № 6. С. 18

11. Солошенко В.М., Векленко В.И., Овчинникова О.А. Эффективность использования ресурсов в растениеводстве Курской области // Вестник Курской государственной сельскохозяйственной академии. 2016. № 9. С. 62-66.

12. Пьяникова Э.А., ТкачеваЕ.Д. Перспективные направления в области производства и переработки продукции растениеводства // Научные труды Северо-Кавказского федерального научного центра садоводства, виноградарства, виноделия. 2019. Т. 26. С. 245-249 